\title{
Corrigendum: The Psychometric Properties of the Grit-O Scale Within the Twente Region in Netherlands: An ICM-CFA vs. ESEM Approach
}

\begin{abstract}
Llewellyn E. van Zyl ${ }^{1,2,3,4 *}$, Chantal Olckers ${ }^{5}$ and Lara C. Roll ${ }^{2,6}$
${ }^{1}$ Department of Industrial Engineering, University of Eindhoven, Eindhoven, Netherlands, ${ }^{2}$ Optentia Research Focus Area, North-West University (VTC), Vanderbij/park, South Africa, ${ }^{3}$ Department of Human Resource Management, University of Twente, Enschede, Netherlands, ${ }^{4}$ Institut für Psychologie, Goethe University, Frankfurt am Main, Germany, ${ }^{5}$ Department of Human Resource Management, University of Pretoria, Pretoria, South Africa, ${ }^{6}$ Department of Applied Psychology, Lingnan University, Tuen Mun, Hong Kong
\end{abstract}

Keywords: confirmatory factor analysis, exploratory structural equation modeling, grit, invariance testing, psychometric properties, validity

\section{A Corrigendum on}

The Psychometric Properties of the Grit-O Scale Within the Twente Region in Netherlands: An ICM-CFA vs. ESEM Approach

by van Zyl, L. E., Olckers, C., and Roll, L. C. (2020). Front. Psychol. 11:796. doi: $10.3389 /$ fpsyg.2020.00796

\section{OPEN ACCESS}

Edited and reviewed by: Riccardo Sartori,

University of Verona, Italy

*Correspondence:

Llewellyn E. van Zy llewellyn101@gmail.com

Specialty section: This article was submitted to Organizational Psychology, a section of the journal Frontiers in Psychology

Received: 30 March 2021 Accepted: 06 April 2021 Published: 06 May 2021

Citation

van Zyl LE, Olckers $C$ and Roll LC (2021) Corrigendum: The Psychometric Properties of the Grit-O Scale Within the Twente Region in Netherlands: An ICM-CFA vs. ESEM Approach. Front. Psychol. 12:688081.

doi: 10.3389/fpsyg.2021.688081
In the original article, there was an omission. In the original published manuscript, a description of the Task Performance Subscale used to establish concurrent validity was omitted from the Measures Section.

A correction has been made to the section Materials and Methods, Measures. The following paragraph is added after the description of the Grit-O Scale, before the section Statistical Analyses:

The Task Performance Subscale of the Individual Work Performance Scale developed by Koopmans et al. (2013) was employed to measure task performance by means of seven items on a 6-point Likert scale ranging from 1 ("Never") to 6 ("Always"). An example of an item is: "I kept in mind the results that I had to achieve in my work." Van Zyl et al. (2019) found acceptable levels of internal consistency for the instrument with a Cronbach's alpha level of 0.88 .

The authors apologize for this error and state that this does not change the scientific conclusions of the article in any way. The original article has been updated.

\section{REFERENCES}

Koopmans, L., Bernaards, C. M., Hildebrandt, V. H., Van Buuren, S., Van der Beek, A. J., and De Vet, H. C. W. (2013). Development of an individual work performance questionnaire. Int. J. Product. Perform. Manag. 62, 6-28. doi: $10.1108 / 17410401311285273$

Van Zyl, L. E., Van Oort, A., Rispens, S., and Olckers, C. (2019). Work engagement and task performance within a global Dutch ICT-consulting firm: the mediating role of innovative work behaviours. Curr. Psychol. doi: 10.1007/s12144-019-00339-1

Copyright $\odot 2021$ van Zyl, Olckers and Roll. This is an open-access article distributed under the terms of the Creative Commons Attribution License (CC BY). The use, distribution or reproduction in other forums is permitted, provided the original author(s) and the copyright owner(s) are credited and that the original publication in this journal is cited, in accordance with accepted academic practice. No use, distribution or reproduction is permitted which does not comply with these terms. 